\title{
A new cluster-brood building species of Plebeia (Hymenoptera, Apidae) from eastern Brazil ${ }^{1}$
}

\author{
Gabriel A. R. Melo² \& Marco A. Costa ${ }^{3}$
}

${ }^{1}$ Contribution nr. 1750 from the Department of Zoology, Universidade Federal do Paraná.

${ }^{2}$ Laboratório de Biologia Comparada Hymenoptera, Univ. Fed. Parana, Dept. Zool., Caixa Postal 19020, BR-81531980 Curitiba-PR, Brazil. garmelo@ufpr.br.

${ }^{3}$ Departamento de Ciências Biológicas, Universidade Estadual de Santa Cruz-UESC, Rodovia Ilhéus-Itabuna km 16, 45662-000, Ilhéus-BA, Brazil. costama@uesc.br

\begin{abstract}
A new cluster-brood building species of Plebeia (Hymenoptera, Apidae) from eastern Brazil. A new species of Plebeia, the second largest genus of stingless bees in the Neotropical region, is described from eastern Brazil. Plebeia grapiuna sp. nov., known only from the lowland forests of southern Bahia, is most similar to P. lucii Moure, a species recently described from Minas Gerais. The lack of yellow marks and the smoother integument of the frons and mesoscutum in P. grapiuna sp. nov. distinguish them. Main features of the nesting habits of the new species are described and illustrated.
\end{abstract}

KEYWORDS. Atlantic forest; Meliponina; Neotropical region; nesting biology; stingless bees.

RESUMO. Uma nova espécie de Plebeia (Hymenoptera, Apidae) do leste do Brasil, com células de cria em cacho. Uma nova espécie de Plebeia, o segundo maior gênero de meliponíneos na região Neotropical, é descrita do leste do Brasil. Plebeia grapiuna sp. nov., conhecida apenas das florestas de terras baixas do sul da Bahia, é semelhante a P. lucii Moure, uma espécie recentemente descrita de Minas Gerais. A ausência de manchas amarelas e o integumento menos rugoso da fronte e do mesoscuto em $P$. grapiuna sp. nov. distinguem as duas espécies. Características principais do hábito de nidificação da nova espécie são descritas e ilustradas.

PALAVRAS-CHAVE. Abelhas sem ferrão; biologia da nidificação; Floresta Atlântica; Meliponina; região Neotropical.

Plebeia, the second largest genus of stingless bees in the Neotropical region, currently contains 38 valid species (Camargo \& Pedro 2007). Fifteen of these names-about $40 \%$ of the genus known diversity-have been proposed in the last fifteen years. The genus richness is likely to be much higher, and when fully revised, it will probably surpass that in Melipona.

The distribution range of Plebeia almost encompass the entire distribution of the stingless bees in the New World, being found from Nuevo Léon, in Mexico (Ayala 1999) to Uruguay, in the south (Camargo \& Pedro 2007). Differently from most stingless bee genera, Plebeia possesses a large number of species either south or north of the $15^{\circ}$ parallels. The fauna of Mexico, for example, contains 11 species of Plebeia, by far the richest stingless bee genus in that country (Ayala 1999).

In this paper, we describe a new species of Plebeia from the Atlantic forest of southern Bahia. The Brazilian Atlantic forest, despite the long history of anthropogenic interference, contains a very rich insect fauna which is still poorly known. Also, as regards to stingless bees, many genera contain endemic species associated to the lowland Atlantic forests of eastern Brazil, as for example Lestrimelitta (Marchi \& Melo 2006), Partamona (Pedro \& Camargo 2003) and Scaura (Melo $\&$ Costa 2004).

\section{MATERIALAND METHODS}

In this study, the morphological terminology follows Michener (2000), except for the propodeal triangle, here the metapostnotum. All measurements are in millimeters. The density of punctation, intervals between punctures, was based on relative puncture diameter, pd (e.g. 2 pd: about $2 x$ the puncture diameter between the punctures). The color images were obtained on camera Leica DFC 500 associated to stereomicroscope MZ 16 and processed by the software Automontage (Syncroscopy). The material cited in this study belongs to the Departamento de Zoologia, Universidade Federal do Paraná, Coleção Pe. J. S. Moure, Curitiba, Brazil (DZUP).

\section{Plebeia grapiuna sp. nov.}

(Figs. 1-12)

Diagnosis and Comments. Plebeia grapiuna sp. nov. is easily distinguished from other species of Plebeia by its small size, lack of yellow marks on the head, mesoscutum and scutellum, by the finely plumose feather-like hairs on frons, finely rugulose anterior portion of mesoscutum, and by the conspicuously areolate metapostnotum. P. grapiuna sp. nov. is apparently restricted to the lowland Atlantic forests of 
southern Bahia, being known only from Ilhéus and Camacan, two localities situated about $80 \mathrm{~km}$ apart. Among the species of Plebeia found in eastern Brazil, P. grapiuna sp. nov. is most similar to $P$. lucii Moure, both having a reduced body size, finely plumose feather-like hairs on the frons (more distinctive in P. grapiuna sp. nov.), rugulose mesoscutum and areolate metapostnotum, as well as in nest characteristics, both species arranging the brood cells in clusters. They differ, however, in their color pattern (P. lucii possesses numerous yellow marks), in the microsculpture of the frons and of the mesoscutum (in P. lucii, the reticulation of the frons is more conspicuous, and the rugosity of the mesoscutum is more pronounced), and in the shorter distance between the anterior lamella of pronotum and pronotal collar (this distance is unusually long in $P$. lucii). Two other available names applied to species of Plebeia from the Atlantic forest, P. mosquito (Smith, 1863) and P. droryana (Friese, 1900), have also to be considered. The callow worker preserved as type specimen of Trigona mosquito in the Natural History Museum (London) has been briefly examined by the first author and photographed a few years ago while in loan to Prof. Moure. It is clearly not closely related to the new species proposed here, being structurally similar to $P$. droryana auctorum and related species. As regards to $P$. droryana, although the type material has not been examined, Friese's description clearly indicates possession of pale markings on the head and mesosoma, what excludes $P$. grapiuna sp. nov.

Description. Worker holotype. Body length: $3.5 \mathrm{~mm}$; maximum head width: $1.4 \mathrm{~mm}$; forewing length: $3.0 \mathrm{~mm}$; maximum width of T2: $1.2 \mathrm{~mm}$. Color: Integument predominantly black (as in Figs. 1-3). Mandibles, scape radicle, last flagellomere, legs (except for reddish brown fore tibia and tarsi), pronotal lobes, tegulae, metanotum, basal half of $\mathrm{T} 1$ and sterna, brown to dark brown. Pronotal collar with two narrow transverse pale yellow stripes. Wing membrane hyaline; veins and pterostigma, dark brown. Pubescence. Predominantly white, except for reddish brown setae on inner surface of tarsi and brown microtrichiae on wings; setae of penicillum and rastellum brown. Face and lateral portion of mesepisternum with conspicuous decumbent finely plumose hairs (as in Figs. 4-6); those on head almost feather-like (as in Fig. 6). Longest erect setae on clypeus with $0.07-0.09 \mathrm{~mm}$ in length; those on scape, with 0.04-0.05 mm; on vertex, with 0.11-0.14 mm. Erect setae on anterior corner of mesoscutum finely plumose, with $0.18-0.25 \mathrm{~mm}$; disc covered with dense, mostly simple, very short pubescence (setae with $0.02-0.04 \mathrm{~mm}$ in length), and a few sparse longer setae, with $0.07-0.09 \mathrm{~mm}$. Longest setae on posterior margin of scutellum with few short branches, and about $0.2-0.25 \mathrm{~mm}$ in length. Erect setae along omaular area plumose, those on lateral mesepisternum mostly simple. Integumental surface: Mostly smooth and shinny, piligerous punctation conspicuous on face and mesoscutum (as in Figs. $3,6)$. Upper half of clypeus and frons weak and finely granulose (more visible at certain light), punctures about 2-5 pd apart. Anterior one-quarter and lateral margins of mesoscutum finely rugulose due to weak transverse and longitudinal wrinkles, respectively; surface between punctures on central and posterior portions of mesoscutum mostly smooth, punctures about 2-4 pd apart. Entire metapostnotum conspicuously areolate. Structure (measurements in $\mathrm{mm}$ ): Space between denticles of mandible in a concave emargination (as in Fig. 7); head about 1.2x wider than long (1.4:1.2); proportion between upper (tangential to lower rim of mid ocellus), maximum and lower interorbital distances, 0.95:1.0:0.72 (0.93:0.98:0.71); clypeus $2.1 \mathrm{x}$ wider than long (0.7:0.33); scape, excluding radicle, about $4.8 \mathrm{x}$ longer than its maximum width $(0.48: 0.1)$; proportion between pedicel, $1^{\text {st }}$ and $2^{\text {nd }}$ flagellomeres 1.4:1.0:0.9 (0.14:0.1:0.09); malar space very narrow, about $0.21 \mathrm{x}$ the diameter of $2^{\text {nd }}$ flagellomere (0.025:0.12); eye about $2.5 x$ longer than its maximum width (0.97:0.38), in lateral view, about $1.3 \mathrm{x}$ wider than maximum width of gena (0.31:0.24); ocelo-orbital distance, in dorsal view, about $0.5 \mathrm{x}$ the distance between posterior ocelli (0.16:0.29). Distance between anterior lamella of pronotum and pronotal collar, measured along midline, short (0.05); scutellum about $2 \mathrm{x}$ wider than long $(0.62: 0.30)$.

Type Material. Worker holotype "Brasil, Bahia, Ilhéus, Campus da UESC, 17.i.2007, Melo \& Costa, em ninho". Paratypes: 8 workers, same data as holotype; 7 workers, "Brasil, Bahia, Ilhéus, Campus da UESC, 10.i.2003, G. Melo \& M. Costa Ninho" "Ninho sob casca de árvore Albizia inopinata"; 5 workers, "Brasil, Bahia, Camacã, Faz. Sta. Bárbara, 200m, $15^{\circ} 23^{\prime} \mathrm{S}, 39^{\circ} 32^{\prime} \mathrm{W}, 14 . \mathrm{i} .2007$, Melo \& Carvalho Fo."; 3 workers, "Brasil, Bahia, Camacã, Faz. Sta. Bárbara, 200m, 15 $23^{\prime}$ S, $39^{\circ} 32^{\prime}$ W, 14.i.2007, Carvalho Fo."; 3 workers, "Brasil, Bahia, Camacã, Faz. Paris, 200m, $15^{\circ} 25^{\prime}$ S, $39^{\circ} 32^{\prime}$ W, 18.i.2008, M. A. Costa \& A. Carvalho Fo., ninho".

Etymology. The name 'grapiuna' is applied to the cocoaproducing region of southern Bahia, as well as a nickname for its inhabitants; from the Tupi-Guarani guirá, bird, plus piuna, dark skin, used here in allusion to the dark integument of the worker bees.

Biology. Four nests of P. grapiuna sp. nov. were found, two underneath the bark of the same live tree (Samanea inopinata, Mimosaceae) in the campus of the Universidade Estadual de Santa Cruz, in Ilhéus, Bahia (Fig. 8), and the other two inside crevices underneath wooden doorframes of buildings (one in the campus of UESC, and the other in the Fazenda Paris, in Camacan). The nest entrances were located between 1 and $1.5 \mathrm{~m}$ above ground. They are small and short tubes made of hardened resin, light (Fig. 10) to dark brown in color. Those in the tree were very inconspicuous and somewhat hidden between the bark cracks, and were found only because of the occasional workers flying toward the nests. Workers of P. grapiuna sp. nov. are very timid and display no aggressive defense behavior, the entrance guards usually hiding within the nest when disturbed.

One of the nests, shown in Figs. 9-12, was dissected. The entrance orifice had an oval shape (Fig. 10) and measured about $3.5 \mathrm{~mm}$ in width and $2.5 \mathrm{~mm}$ in height. The orifice opened in a relatively large entrance tunnel, about 6-7 $\mathrm{mm}$ in width. The nest was built in the narrow space (ca. 1 to $1.5 \mathrm{~cm}$ ) between 

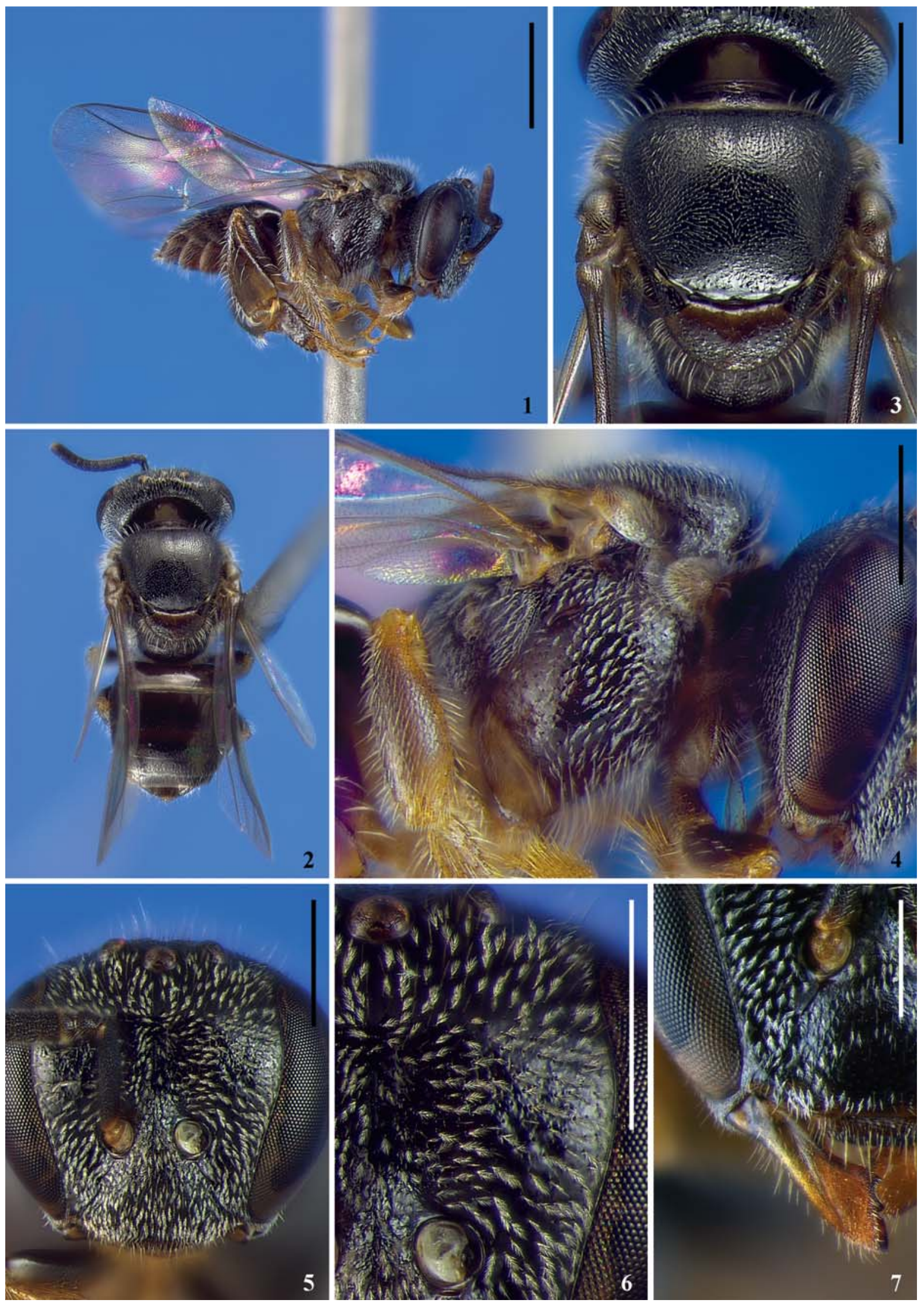

Figs. 1-7. Plebeia grapiuna sp. nov., worker paratype from Ilhéus, Bahia (Figs. 1-6) and worker paratype from Camacan, Bahia (Fig. 7). 1, Habitus, lateral view. 2, Same, dorsal view. 3, Detail of the mesosoma, dorsal view. 4, Same, lateral view. 5, Head, frontal view. 6, Detail of frons, frontal view. 7, Detail of head, frontal view (scale bar: $0.3 \mathrm{~mm}$ ). Figs. 1 and 2 at same scale (scale bar: $1 \mathrm{~mm}$ ); scale bar of Figs. 3-6: 0.5 mm; scale bar of Fig. 7: $0.3 \mathrm{~mm}$. 

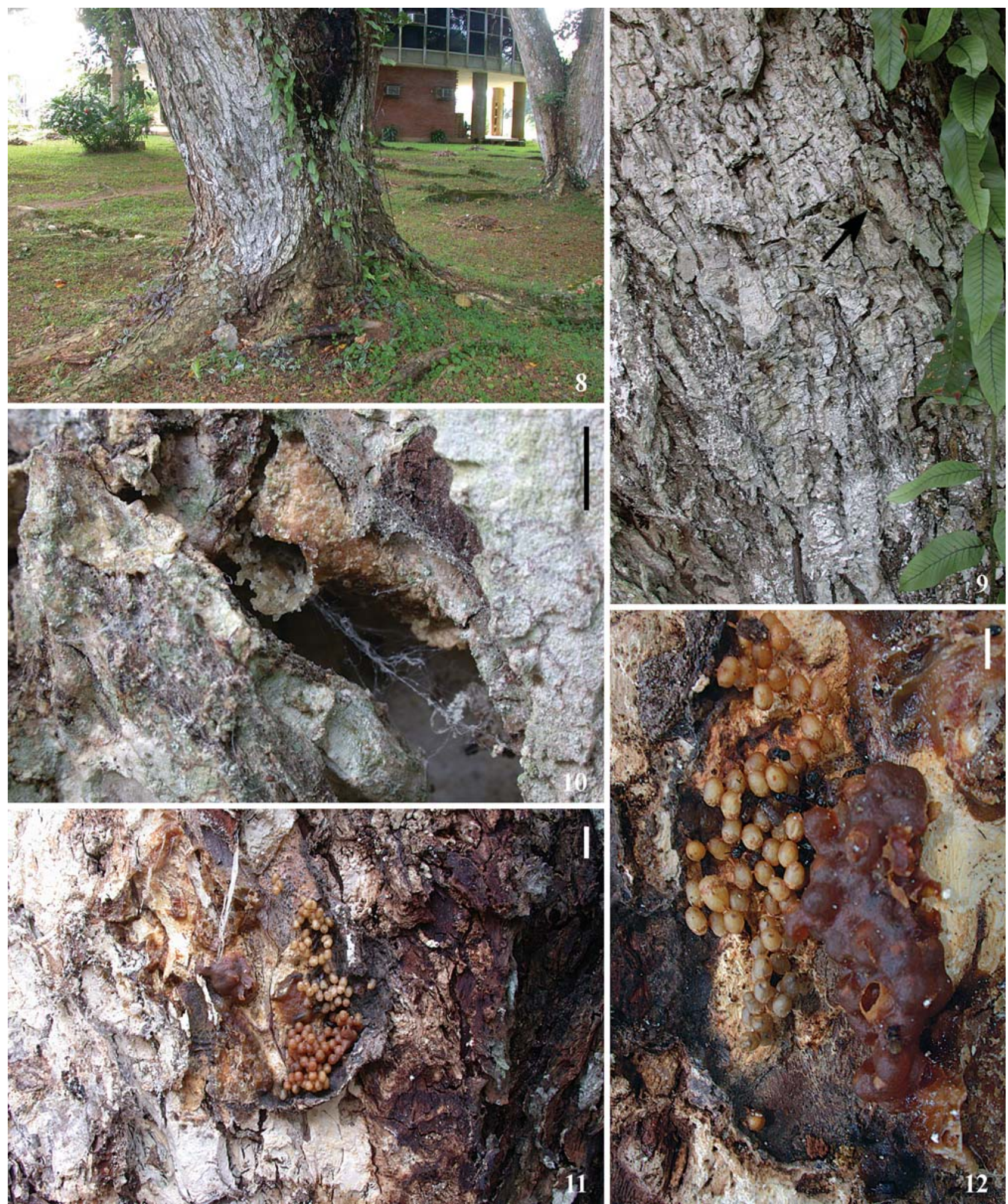

Figs. 8-12. Plebeia grapiuna sp. nov., nesting habits. 8, Base of tree trunk (Samanea inopinata), at the campus of the Universidade Estadual de Santa Cruz, in which two nests were found. 9, Closer view of the tree bark, with black arrow pointing to entrance tube. 10. Close-up view of the entrance tube. 11. Interior of the nest (portion that remained attached to the trunk after the nest was opened), showing brood cell cluster (center right) and small block of food pots (center left); part of the nest batumen appears as the dark sheath below and at the right of the cell clusters. 12, Detail of nest interior (portion that remained attached to the piece of bark covering the nest chamber), showing part of the cell clusters and a large block of food pots (at the left); a large deposit of stick resin appears at the upper right corner. Scale bars of Figs. 10 and 12: 5 mm; scale bar of Fig. 11: $10 \mathrm{~mm}$. 
adjacent bark pieces of the outermost bark layer. There was clear evidence that the workers expand the nest chamber by scraping the soft inner layers of the bark. Examination of bark pieces covering the nest chamber, under a dissecting microscope, showed large areas in which the inner layers have been removed.

The entire nest chamber had an irregular shape and measured about $11 \times 8 \mathrm{~cm}$. The chamber was sealed by a 1-1.5 $\mathrm{mm}$ layer of dark hardened resin mixed with bark chips. Most of the inner space was occupied by the brood cells, food pots and large deposits of stick resin. The brood cells were arranged in clusters, lacking any sort of involucrum around them. Worker cells measured about $4 \times 2.5 \mathrm{~mm}$, while one larger queen cell found had $5 \times 3 \mathrm{~mm}$. The food pots formed three compact blocks, a larger one with $54 \times 25 \mathrm{~mm}$, and two smaller with about $23 \times 23 \mathrm{~mm}$. They were located between the end of the entrance tunnel and the brood cells. Each food pot had about 6-7 mm in diameter. Although the total number of workers was not counted, the nest had a small population, less than 100 workers in total. Regarding inquilines, very small white acari were observed inside the nest.

Besides $P$. grapiuna sp. nov., construction of brood cells in clusters is found in a few other species of Plebeia, including P. lucii, P. minima (Gribodo, 1893) and P. tica (Wille, 1969) (Wille 1969; Roubik 1983; Drumond et al. 2000; Moure 2004).

Acknowledgements. We would like to thank Vitor Becker for granting access to the forest reserves under his care in southern Bahia; to Anthony Raw and Antonio Carvalho Filho for assistance during field work; to Lisiane D. Wendt (Taxon line - UFPR) for assistance in image capture and use of the software Automontage.

\section{REFERENCES}

Ayala, R. 1999. Revision de las abejas sin aguijon de Mexico (Hymenoptera: Apidae: Meliponini). Folia Entomológica Mexicana 106: $1-123$.

Camargo, J. M. F. \& S. M. R. Pedro. 2007. Meliponini, pp. 272-578. In: J. S. Moure, D. Urban \& G. A. R. Melo (Orgs). Catalogue of Bees (Hymenoptera, Apoidea) in the Neotropical Region. Curitiba, Sociedade Brasileira de Entomologia. xiv+1058 p.

Drumond, P. M.; R. Zucchi \& B. P. Oldroyd. 2000. Description of the cell provisioning and oviposition process of seven species of Plebeia Schwarz (Apidae, Meliponini), with notes on their phylogeny and taxonomy. Insectes Sociaux 47: 99-112.

Marchi, P. \& G. A. R. Melo. 2006. Revisão taxonômica das espécies brasileiras de abelhas do gênero Lestrimelitta Friese (Hymenoptera, Apidae, Meliponina). Revista Brasileira de Entomologia 50: 6-30.

Melo, G. A. R. \& M. A. Costa. 2004. A new stingless bee species of the genus Scaura (Hymenoptera, Apidae) from the Brazilian Atlantic forest, with notes on S. latitarsis (Friese). Zootaxa 544: 1-10

Michener, C. D. 2000. The Bees of the World. Baltimore, The Johns Hopkins University Press. 913 p.

Moure, J. S. 2004. Duas espécies novas de Plebeia Schwarz do Brasil (Hymenoptera, Apidae, Meliponinae). Revista Brasileira de Entomologia 48: 199-202.

Pedro, S. R. M. \& J. M. F. Camargo. 2003. Meliponini neotropicais: o gênero Partamona Schwarz, 1939 (Hymenoptera, Apidae). Revista Brasileira de Entomologia 47: 1-117.

Roubik, D. W. 1983. Nest and colony characteristics of stingless bees from Panamá (Hymenoptera: Apidae). Journal of the Kansas Entomological Society 53: 327-355.

Wille, A. 1969. A new species of stingless bee Trigona (Plebeia) from Costa Rica, with descriptions of its general behavior and clustertype nest. Revista de Biologia Tropical 15: 299-313. 